\title{
Electricity generation and microbial communities in microbial fuel cell powered by macroalgal biomass
}

Zhao, Nannan; Jiang, Yinan; Alvarado-Morales, Merlin; Treu, Laura; Angelidaki, Irini; Zhang, Yifeng

Published in:

Bioelectrochemistry

Link to article, DOI:

10.1016/j.bioelechem.2018.05.002

Publication date:

2018

Document Version

Peer reviewed version

Link back to DTU Orbit

Citation (APA):

Zhao, N., Jiang, Y., Alvarado-Morales, M., Treu, L., Angelidaki, I., \& Zhang, Y. (2018). Electricity generation and microbial communities in microbial fuel cell powered by macroalgal biomass. Bioelectrochemistry, 123, 145-149. https://doi.org/10.1016/j.bioelechem.2018.05.002

\section{General rights}

Copyright and moral rights for the publications made accessible in the public portal are retained by the authors and/or other copyright owners and it is a condition of accessing publications that users recognise and abide by the legal requirements associated with these rights.

- Users may download and print one copy of any publication from the public portal for the purpose of private study or research.

- You may not further distribute the material or use it for any profit-making activity or commercial gain

- You may freely distribute the URL identifying the publication in the public portal 


\section{Accepted Manuscript}

Electricity generation and microbial communities in microbial fuel cell powered by macroalgal biomass

Nannan Zhao, Yinan Jiang, Merlin Alvarado-Morales, Laura Treu, Irini Angelidaki, Yifeng Zhang

PII: $\quad$ S1567-5394(18)30158-0

DOI: $\quad$ doi:10.1016/j.bioelechem.2018.05.002

Reference: BIOJEC 7159

To appear in: Bioelectrochemistry

Received date: $\quad 11$ April 2018

Revised date: $\quad 2$ May 2018

Accepted date: $\quad 2$ May 2018

Please cite this article as: Nannan Zhao, Yinan Jiang, Merlin Alvarado-Morales, Laura Treu, Irini Angelidaki, Yifeng Zhang, Electricity generation and microbial communities in microbial fuel cell powered by macroalgal biomass. The address for the corresponding author was captured as affiliation for all authors. Please check if appropriate. Biojec(2018), doi:10.1016/j.bioelechem.2018.05.002

This is a PDF file of an unedited manuscript that has been accepted for publication. As a service to our customers we are providing this early version of the manuscript. The manuscript will undergo copyediting, typesetting, and review of the resulting proof before it is published in its final form. Please note that during the production process errors may be discovered which could affect the content, and all legal disclaimers that apply to the journal pertain. 
Electricity generation and microbial communities in microbial fuel cell powered by macroalgal biomass

Nannan Zhao, Yinan Jiang, Merlin Alvarado-Morales, Laura Treu, Irini Angelidaki, Yifeng Zhang* Department of Environmental Engineering, Technical University of Denmark, DK-2800 Lyngby, Denmark

${ }^{*}$ Corresponding author, Tel.: +45 45251410; fax: +4545932850 .

E-mail address: yifz@env.dtu.dk; yifzmfc@gmail.com (Yifeng Zhang) 


\begin{abstract}
The potential of macroalgae Laminaria digitata as substrate for bioelectricity production was examined in a microbial fuel cell (MFC). A maximum voltage of $0.5 \mathrm{~V}$ was achieved without any lag time due to the high concentration of glucose and mannitol in the hydrolysate. Total chemical oxygen demand removal efficiency reached over $95 \%$ at the end of batch run. Glucose and mannitol were degraded through isobutryrate as intermediate. The 16S rRNA gene high throughout sequencing analysis of anodic biofilm revealed complex microbial composition dominated by Bacteroidetes (39.4\%), Firmicutes (20.1\%), Proteobacteria (11.5\%), Euryarchaeota (3.1\%), Deferribacteres (1.3\%), Spirochaetes (1.0\%), Chloroflexi (0.7\%), Actinobacteria (0.5\%), and others (22.4\%). The predominance of Bacteroidetes, Firmicutes and Proteobacteria demonstrated their importance for substrate degradation and simultaneous power generation. These results demonstrate that macroalgae hydrolysate can be used as a renewable carbon source of microbial electrochemical systems for various environmental applications.
\end{abstract}

\title{
Keywords
}

Macroalgae hydrolysis; Laminaria digitata; Bioelectricity; Microbial fuel cell; 16S rRNA microbial analysis 


\section{Introduction}

The environmental threads due to extensive use of fossil fuels have motivated the search for alternative sources of energy [1-3]. Bioenergy, which refers to the energy generated by biomass has great potential as renewable resource $[4,5]$. Among the various types of biomass, macroalgae is an attractive candidate due to its high content of carbohydrates, high biodegradability, and high growth rates [6,7]. Many studies have focused on the utilization of macroalgae for bioenergy purposes including mainly biogas production via anaerobic digestion and bioethanol and biochemicals production by fermentation [8-10]. Though macroalgae can be used for biogas or bioethanol production, economic constraints point to alternative products and technologies for feasible utilization of this biomass.

Microbial fuel cells (MFCs) offer a possibility to directly generate electrical power from various kinds of organic-rich wastes and biomasses while treating them $[6,7,11]$. Generally, an MFC is composed of an anode and a cathode separated by a proton exchange membrane. In the anode, the exoelectrogenic microorganisms, as biocatalysts, oxidize organic matter into electrons, protons and carbon dioxide. The electrons are transferred to the cathode via external circuit, and protons are diffused into cathode through membrane. Oxygen or another oxidant combines with electrons and protons in cathode. By this process, the energy stored in organics can be converted to electricity, which could be used directly.

Compared to the conventional biogas or bioethanol production from macroalgae, producing bioelectricity from macroalgal biomass has the advantage of avoiding energy conservation and transportation cost. The concept of using macroalgae (Ulva lactuca) as substrate in MFC for electricity production has been previously reported [6, 7]. However, in Velasquez-Orta's study, the biomass utilization efficiency in terms of TCOD removal in MFC powered by Ulva lactuca was relatively low (maximum 73\% removal of TCOD), probably because the macroalgae in the form of powder were not pretreated and thereby not fully biodegradable. It has been reported [8] that after hydrolysis of macroalgae (Laminaria digitata), the complex sugars could be decomposed into simple monosaccharides (such as glucose). Thus, pretreatment of macroalgal biomass such as by enzymatic hydrolysis might improve the substrate (biomass) utilization in MFC. The feasibility of such process has never been reported. Furthermore, it is important to explore the 
microbial communities on the anode capable of electricity production and macroalgal biomass utilization. Elucidation of the microbial composition would assist future construction of effective microbial consortia in order to enhance the output of the process.

Based on previous biogas study [8], it was shown that the hydrolysate of Laminaria digitate was rich in glucose. It has been demonstrated that glucose, is a suitable fuel for MFCs [12-14]. In this context, $L$. digitata hydrolysate could be a potential substrate in MFC for electricity production, which has never been investigated. Accordingly, the aim of this study was to generate directly electrical power from L. digitate in an MFC. Moreover, the microbial community was analyzed to explore the function of microorganisms that were responsible for the degradation of macroalgae hydrolysate in MFC. This study is the first attempt to broaden the utilization of the macroalgae species L. digitata into bioelectricity production. It may offer another sustainable and effective way to produce power from macroalgal biomass.

\section{Material and methods}

\subsection{Algae characteristics and hydrolysis}

L. digitata was collected at Hamborg Strand (north of Hanstholm at the Danish North Sea coast) and was stored at $-20{ }^{\circ} \mathrm{C}$ before use. As described before [8], L. digitata was dried at $50{ }^{\circ} \mathrm{C}$ for four days until the moisture content was $<10 \%$. Then it was mechanically cut into pieces $(<2 \mathrm{~mm})$ and grounded into powder for the following hydrolysis. The hydrolysis was performed with the help of relevant enzymes as described before [8]. L. digitata hydrolysate was used for starting-up the MFC. The characteristics of hydrolysate were tested: $\mathrm{pH} 5.0 \pm 0.1$, total solid $54.4 \pm 0.6 \%$, and volatile solid $50.4 \pm 0.2 \%$.

\subsection{MFC construction and operation}

An MFC made of nonconductive polycarbonate plates was set up as previously described [15]. The anode chamber $(5 \times 5 \mathrm{~cm})$ and cathode chamber $(5 \times 5 \mathrm{~cm})$ was separated by a cation exchange membrane (CEM, CMI 7000, Membrane international, NJ). To avoid leakage, rubber gaskets and screws were used to tighten the reactors. The anode and cathode materials were carbon brush $(5.0 \mathrm{~cm}$ in diameter, $5.0 \mathrm{~cm}$ in length, MillRose, USA) and a titanium woven wire mesh $(4 \times 5 \mathrm{~cm}, 0.15 \mathrm{~mm}$ aperture, William Gregor Limited, London) 
coated with $0.5 \mathrm{mg} / \mathrm{cm}^{2} \mathrm{Pt}$, respectively. The anode and cathode were connected by a $1000 \Omega$ resistance externally. An external recirculation bottle $(500 \mathrm{ml})$ was connected to the anode chamber to increase the volume of anodic compartment. The external bottle was agitated at $250 \mathrm{rpm}$ to ensure anodic medium fully mixed. The recirculation flow rate was $40 \mathrm{ml} / \mathrm{min}$.

To enrich exoelectrogenic biofilm on the anode, $300 \mathrm{ml}$ domestic wastewater collected from a primary clarifier (Lundtofe Wastewater Treatment Plant, Lyngby, Denmark) was used as the medium and $1 \mathrm{~g} \mathrm{~L}^{-1}$ glucose was added as substrate to acclimate the electroactive bacterial consortia. In the cathode, $45 \mathrm{ml}$ ferricyanide solution $(50 \mathrm{mM})$ was used as the catholyte. It should be noted here, the ferricyanide was only used during the enrichment period. Every week when the voltage decreased below $0.1 \mathrm{~V}$, the anodic and cathodic solutions were replaced with fresh ones. After around one month, when the voltage of MFC could achieve maximum $0.5 \pm 0.05 \mathrm{~V}$ every time after changing the fresh solutions, indicating that electrochemically active microorganisms had colonized the surface of anode for the successful starting-up of MFC. After the successful enrichment, $9 \mathrm{ml} \mathrm{L}$. digitata hydrolysate and $291 \mathrm{ml}$ domestic wastewater were mixed as anodic electrolyte for the experiment. Every two or three days, the anodic solution was sampled and stored in the freezer at $-20{ }^{\circ} \mathrm{C}$ for later analysis. Once the experiments were completed, the samples for the microbial analysis were obtained as described below. All the experiments were conducted in duplicate at room temperature.

\subsection{Electrochemical analysis}

The glucose and mannitol concentrations in hydrolysate were measured using high performance liquid chromatography (HPLC, Agilent) as previously described [12]. $\mathrm{H}_{2} \mathrm{SO}_{4}$ of $0.04 \mathrm{M}$ was used as eluent and flow rate was set to $0.6 \mathrm{ml} / \mathrm{min}$ with a Bio-Rad Aminex HPX-87H column $(300 \mathrm{~mm} \times 7.8 \mathrm{~mm})$, and temperature was set to $63.5^{\circ} \mathrm{C}$. The volatile fatty acids (VFA) were measured by a GC with FID detection (Agilent 6890). The $\mathrm{pH}$ was tested using a PHM $210 \mathrm{pH}$ meter (Radiometer). Total chemical oxygen demand (TCOD) was determined as previous study [16]. Voltage across the resistor was recorded by a digital multimeter (model 2700, Keithley Instruments, Inc,; Cleveland, OH) every 30 min. Power density 
$\left(\mathrm{P}_{\mathrm{d}}=\mathrm{IV} / \mathrm{A}\right)$, and Coulombic efficiency were calculated as previously described [17] with the power density normalized by the projected surface area of the anode.

\subsection{Microbial analysis}

Biofilm samples were cut off from carbon brush as previously described [18] by using sterilized scalpel at the end of experiment. Total DNA extraction was performed using the Powersoil DNA isolation kit (MoBio PowerSoil, Carlsbad, CA USA) and stored at $-20{ }^{\circ} \mathrm{C}$ before doing the freeze dry. Total genomic DNA was further amplified using 16S rRNA gene universal primers 515F/806R (V4 hypervariable region) and amplicons were sequenced by Illumina MiSeq desktop sequencer (Ramaciotti Centre for Genomics, Kensington, Australia). Raw data can be obtained from the Sequence Read Archive [6] database (http://www.ncbi.nlm.nih.gov/sra) under the accession number PRJNA412459. The raw 16S rRNA gene sequences were analyzed using microbial genomics module plug of CLC Workbench software (V.8.0.2, QIAGEN). Reads trimming and operational taxonomic units (OTUs) clustering were performed as previously described [19]. The final taxonomical assignment of the most interesting OTUs was performed including a manual comparison of CLC results with 16S ribosomal RNA sequences (Bacteria and Archaea) database at the National Center for Biotechnology Information (NCBI) by using BLAST. In order to facilitate data interpretation, the microbial relative abundance was depicted as a heat map using Multi experiment viewer software (MeV 4.9.0) [20]. 


\section{Results and discussion}

3.1 Hydrolysis of the macroalgae

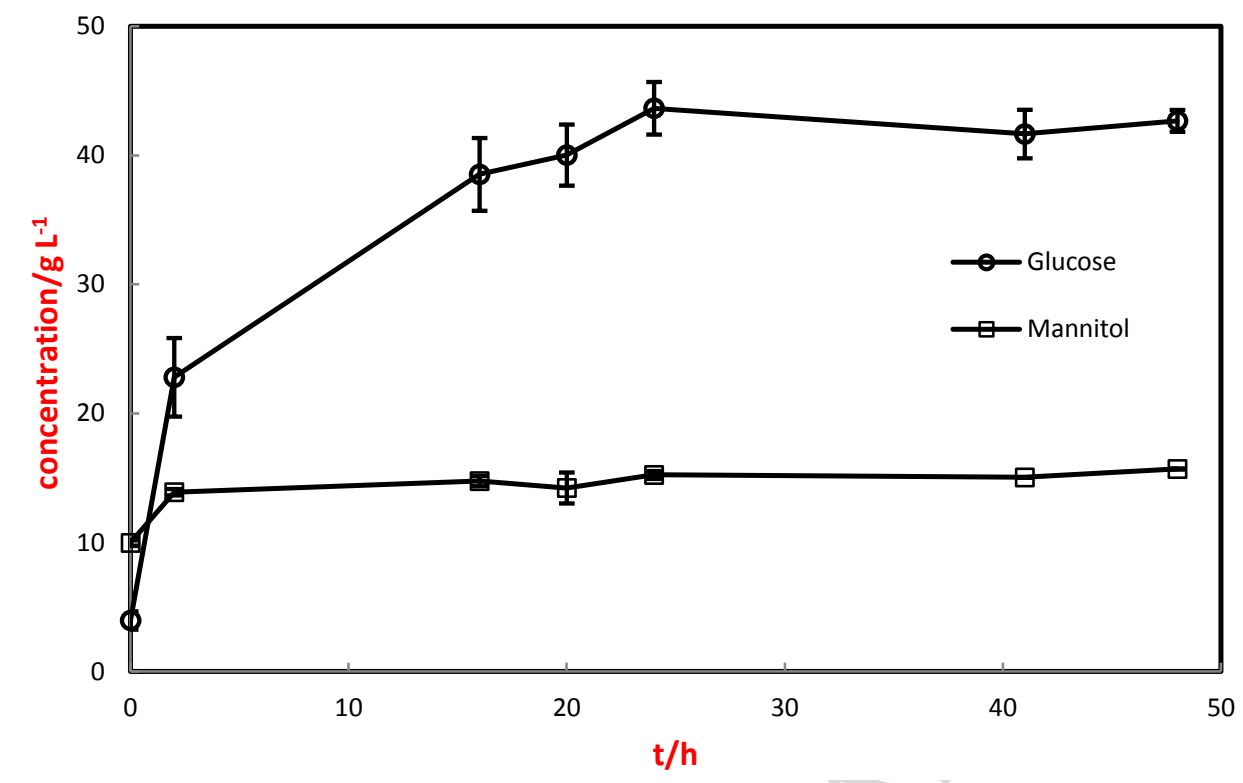

Figure. 1 Enzymatic hydrolysis profile of the released sugars

During the enzymatic hydrolysis of the raw $L$. digitata, glucose and mannitol were released as shown in Fig.1. The glucose concentration showed a gradual increase up to $43.65 \mathrm{~g} \mathrm{~L}^{-1}$ after $24 \mathrm{~h}$ and a slight decrease between 24 and 48 h. Mannitol was released quickly in the first 2 hours, demonstrating faster hydrolysis rates compared to glucose at the hydrolysis conditions applied. After the first 2 hours, the mannitol concentration was stable around $14 \mathrm{~g} \mathrm{~L}^{-1}$. Overall, the final concentrations of glucose and mannitol in the hydrolysate achieved 42.67 and $15.70 \mathrm{~g} \mathrm{~L}^{-1}$, respectively. In terms of the levels of released sugars, the hydrolysis of $L$. digitata kept the same level with that of previous studies [8]. Similarly, the combined sugar yield was achieved at $77 \% \mathrm{w} / \mathrm{w}$ of dried macroalgae, with regard to $69 \%$ accounting for glucose and $8 \%$ for mannitol, respectively [8].

3.2 Power output and TCOD removal in MFC powered by Laminaria digitata hydrolysate 


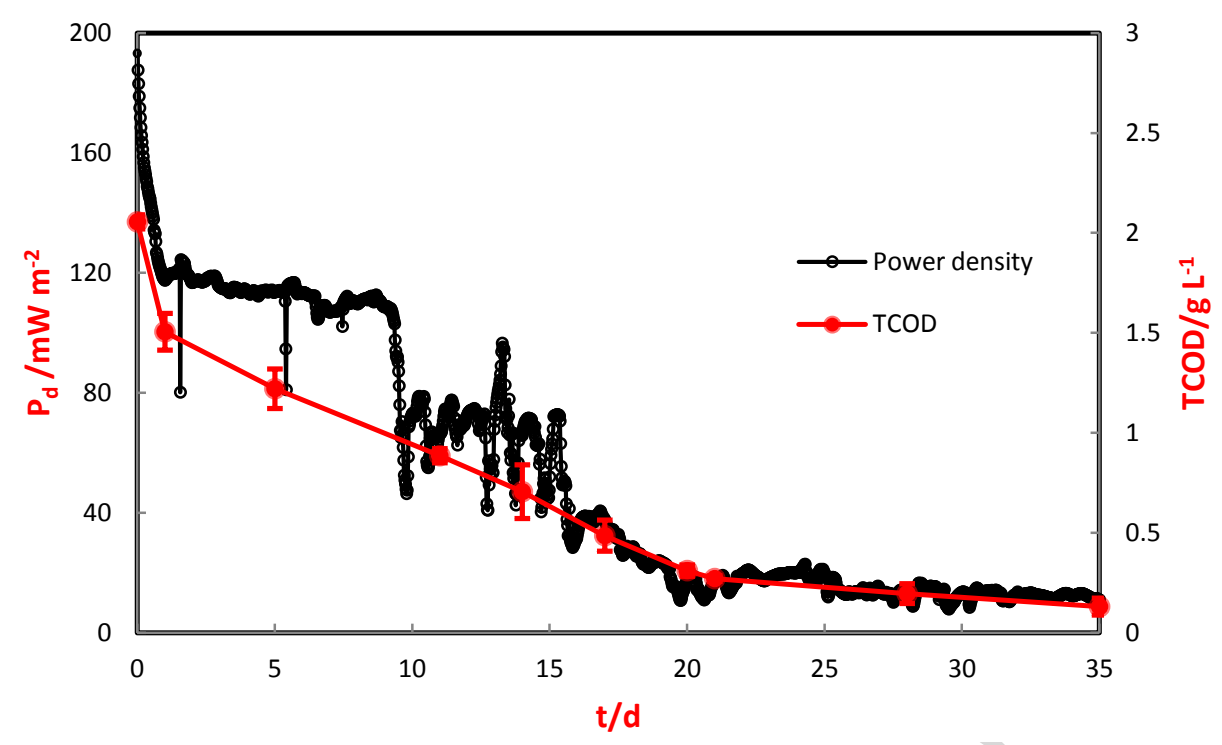

Figure. 2 Time course of power generation and TCOD removal in MFC with $L$. digitata hydrolysate as substrate.

As previously mentioned glucose is a suitable substrate for electricity generation in MFC [12, 21, 22]. Therefore, L. digitata hydrolysate with a content of glucose $\left(44 \mathrm{~g} \mathrm{~L}^{-1}\right)$, could be favorable substrate for electricity production in MFC, which was investigated in batch mode in this section. When MFC was fed with hydrolysate at a concentration of $2 \mathrm{~g} \mathrm{TCOD} \mathrm{L}^{-1}$, a steady state power density of $120 \pm 5 \mathrm{~mW} \mathrm{~m}^{-2}(0.5 \pm$ $0.02 \mathrm{~V}$ ) with a period of around 9 days was rapidly achieved (Fig. 2). Accordingly, TCOD concentration gradually decreased with operation time from the initial $2.06 \pm 0.04$ to $0.89 \pm 0.03 \mathrm{~g} \mathrm{~L}^{-1}$ after 11 days operation, resulting in a removal efficiency of $56.9 \pm 0.1 \%$. The corresponding coulombic efficiency was $10.0 \pm 0.1 \%$. Previous study [21] reported that low coulombic efficiency was generally because of substrate consumption by non-electricity-generating bacteria. The relative low coulombic efficiency in present study could be explained by the wide spectrum of fermentative bacteria that can utilize glucose and thereby compete with electroactive bacteria for glucose as substrate. Following a stable period, power generation gradually decreased from 110 to $17 \mathrm{~mW} \mathrm{~m}^{-2}$ in the following 11 days except sharp decrease at day 10 . The decrease was most likely due to the depletion of glucose and mannitol, which was coincided with reduced 
TCOD from 0.89 to $0.31 \mathrm{~g} \mathrm{~L}^{-1}$. In the last 15 days, the power density kept relatively stable between 20 and $15 \mathrm{~mW} \mathrm{~m}^{-2}$ with slight fluctuation, and the corresponding TCOD showed the similar tendency (slow decrease from 0.31 to $0.13 \mathrm{~g} \mathrm{~L}^{-1}$ ). The subsequent coulombic efficiency increased slowly from 10.0 to $12.5 \%$, and the overall TCOD removal efficiency reached $95 \%$ at the end of experiment.

\subsection{Variations of VFA and pH during operation}

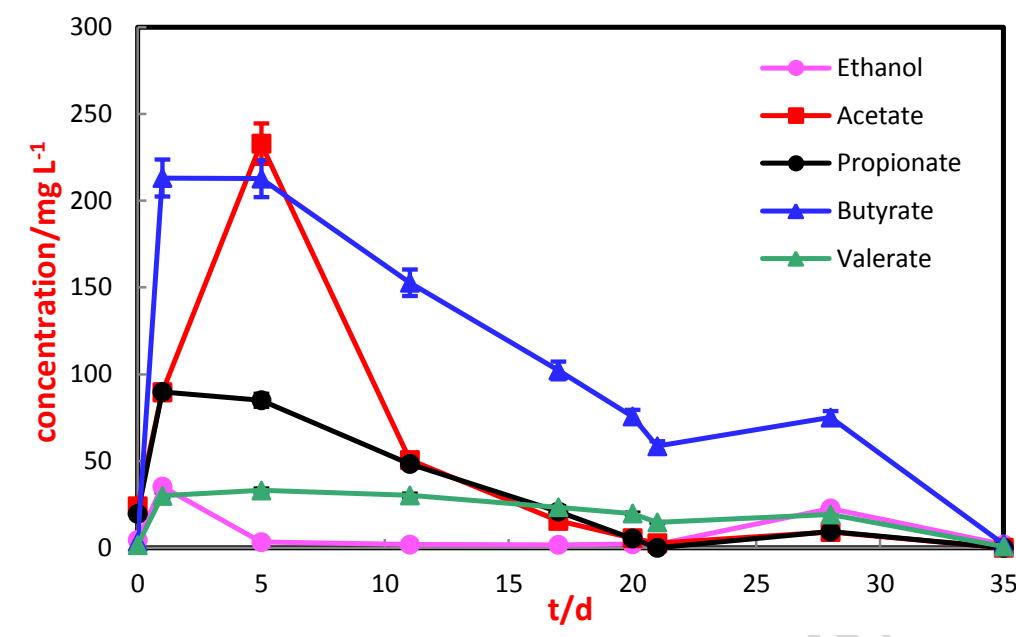

Figure. 3 Variations of VFA concentrations during organic degradation in anode

During the oxidation of organics in anode, intermediate by-products are formed. In the first 5 days, the main intermediate products were acetate, butyrate, propionate, valerate and ethanol (Fig.3). The other VFAs including isobutyrate, propanol and hexanoate were lower than detection limit $\left(10 \mathrm{mg} \mathrm{L}^{-1}\right)$ (data not shown here). Specifically, as shown in Fig.4, acetate and butyrate concentrations increased from 0 to 232.94 and $212.76 \mathrm{mg} \mathrm{L}^{-1}$, respectively in the first 5 days, and decreased gradually afterwards. Likewise, the other three VFAs levels showed similar trend. The distributions of VFAs demonstrated the organic oxidation way: sixhydrocarbon sugars (glucose and mannitol) were degraded into four-hydrocarbon sugar (butyrate), followed by the butyrate oxidation to propionate or acetate, and then oxidized to $\mathrm{CO}_{2}$. The VFA results obtained here were consistent with previous study, in which glucose as substrate was mainly degraded to acetate and then further oxidized [23]. The different distributions of intermediates will be further explained with microbial analysis. 


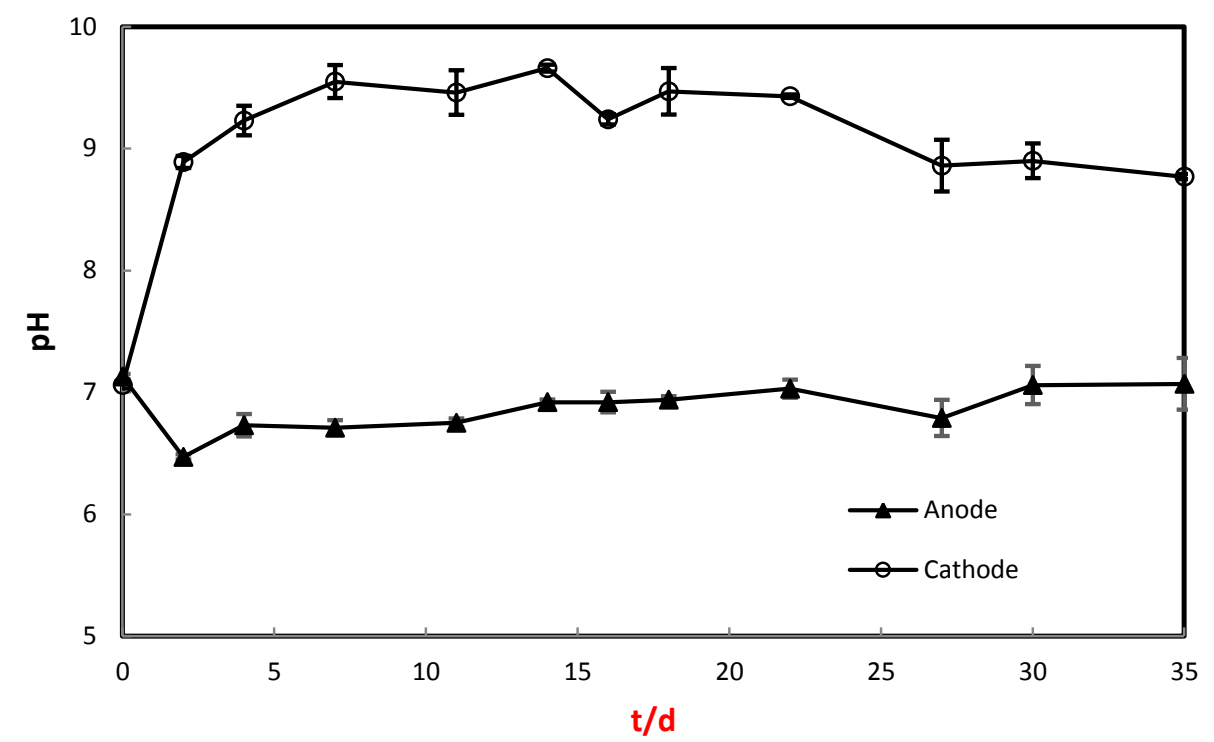

Figure. 4 Anodic and cathodic $\mathrm{pH}$ changing with time

The variations of $\mathrm{pH}$ in anode and cathode were monitored throughout the experimental period (Fig. 4). The cathodic $\mathrm{pH}$ increased immediately from 7 to 8.9 while anodic $\mathrm{pH}$ decreased from 7 to 6.5 at day 2 . The main reason could be the low efficient of proton transfer from anode to cathode which led to the consumption of proton from water for oxygen reduction and accumulation of hydroxide ions in the cathode. Similarly, the proton accumulation in anode caused a lower $\mathrm{pH}$ (6.5), which was also contributed by the high concentrations of VFAs. The results observed here were in agreement as previously reported [24, 25]. After 2 days, the cathodic $\mathrm{pH}$ exhibited a slow increase and achieved the highest value of 9.6 at day 14, where it decreased to 8.7 at the end of experiment. In the case of anodic $\mathrm{pH}$, it fluctuated around 7. 
3.4 Microbial community analysis

(A)

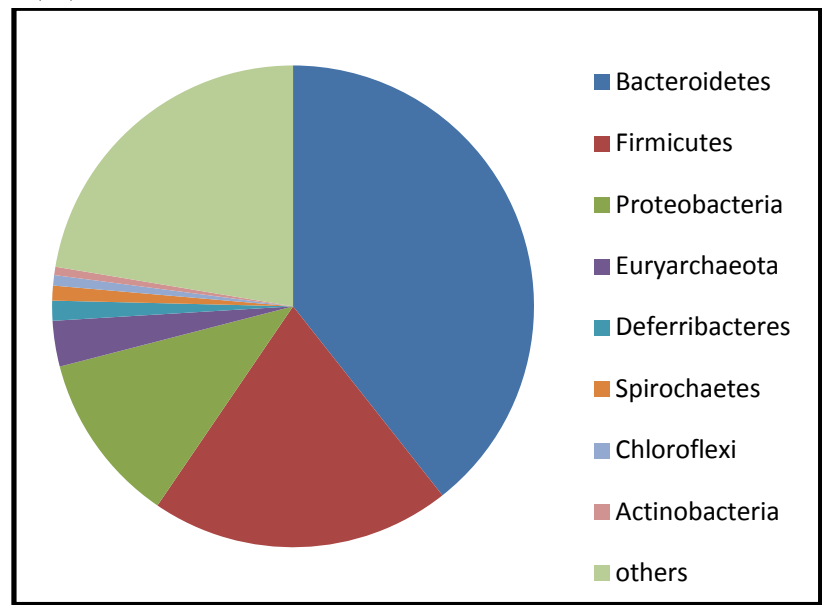

(B)

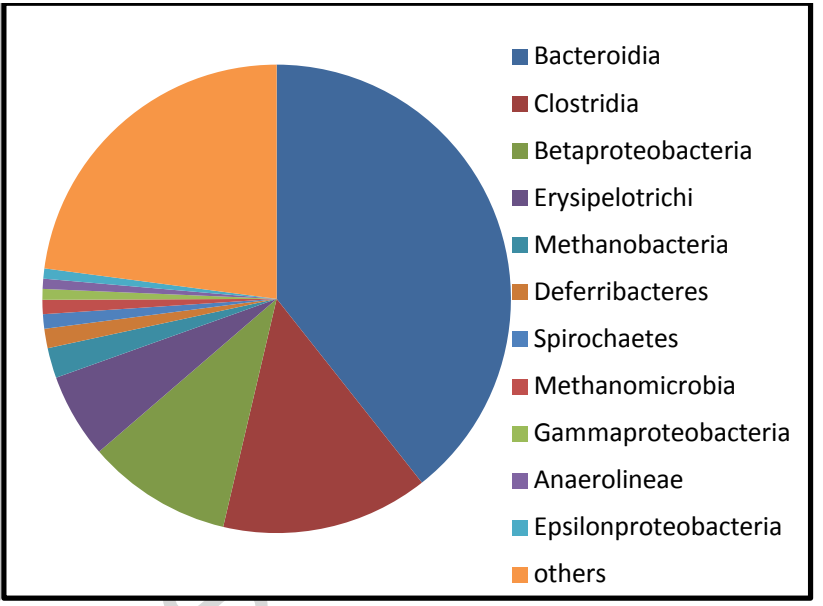

Figure. 5 Microbial community structures at phylum (A) and class (B).

In order to get further insight to the role of microorganisms in electricity generation, the microbial community established on the anodic biofilm was analyzed using 16S rRNA gene sequences approach (Fig. 5 and supplementary info). As reported previously [12, 26, 27], it showed diverse bacterial community in MFC anode mainly because glucose supports growth of many different fermentative bacteria. At phylum level, bacterial species in anode biofilm was dominated by Bacteroidetes (39.4\%), Firmicutes (20.1\%), and Proteobacteria (11.5\%), followed by Euryarchaeota (3.1\%), Deferribacteres (1.3\%), Spirochaetes (1.0\%), Chloroflexi (0.7\%), Actinobacteria (0.5\%), others (22.4\%). In the community, Bacteroidetes, Firmicutes, and Proteobacteria were the three most abundant phyla (Fig. 5A). Similarly, it was previously reported the enrichment of Bacteroidetes in the biofilm of glucose-enriched MFC [12]. Additionally, the presence of Actinobacteria also reflected its assistance in organic degradation since they are known to be members among versatile hydrocarbon degraders $[28,29]$.

Fig. 5B presented the community distribution at class level. Correspondingly, Bacteroidia (39.4\%) which belonged to the phylum Bacteroidetes was dominant, followed by Clostridia (14.3\%) and Erysipelotrichi (5.9\%) which belonged to Firmicutes. Three classes within Proteobacteria were Betaproteobacteria (10.0\%), Gammaproteobacteria (0.7\%) and Epsilonproteobacteria (0.7\%), respectively. The predominance of 
Firmicutes and Proteobacteria class in the bacterial community in MFCs was also reported by others. Chae et al. [21] found the highest dominance of Proteobacteria (62\%) in the glucose-fed MFC, whereas the proliferation of Firmicutes (59.3\%) in propionate-enriched MFC. Jung et al. reported that Firmicutes were found only in glucose-fed MFCs regardless of other substrates like acetate and lactate [30]. Firmicutes have been reported to be exoelectrogens capable of exocellular electron transfer [31, 32] and able to convert glucose into simple organics [30]. Herein, due to the high concentration of glucose in hydrolysate, Firmicutes were enriched on the biofilm. Proteobacteria were also proposed as possible exoelectrogens [28], particularly the classes of Gamma- and Betaproteobacteria.

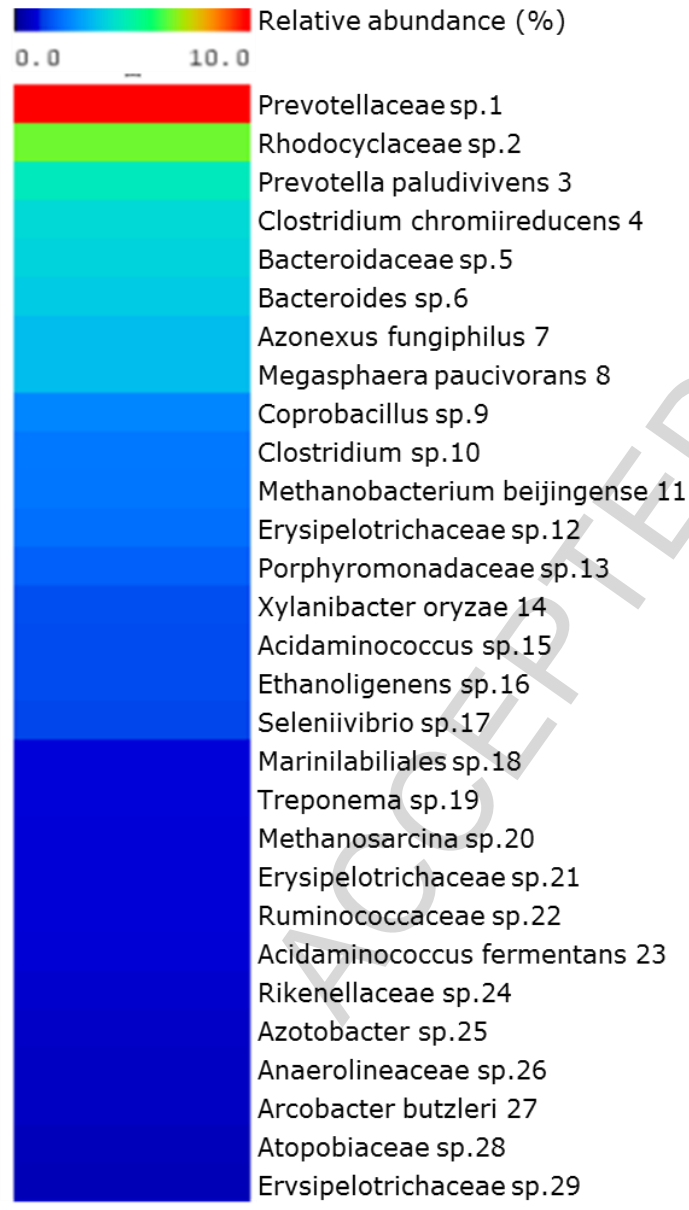

Figure. 6 Heat map analysis of bacterial community structures at genus level. 
The genus level characterization further illustrates the functional roles of microbes in the MFC community. As shown in Fig. 6, Prevotellaceae sp. (23.0\%) were the most dominant taxon of the community, followed by Rhodocyclaceae sp. (6.6\%), Prevotella paludivivens (4.6\%), Clostridium chromiireducens (4.1\%) and others (lower than 4\%). Prevotellaceae are known as fermentative microorganisms using glucose producing hydrogen besides volatile fatty acids. Considering their dominance in the anode, once the electrons were released from organics, Prevotellaceae consumed the electrons at the anode, leaving fewer electrons to flow to cathode, and thereby resulting in low coulombic efficiency. The predominance of Prevotellaceae was consistent with the lower coulombic efficiency observed before (Section 3.2). Rhodocyclaceae sp., described as short-chain fatty acid utilizers [33], were found in the sample, which was consistent with VFA results. Rhodocyclaceae, known to reduce iron [34], were previously observed to dominate anodic biofilm in MFCs $[35,36]$. The Clostridium chromiireducens, which was isolated from $\mathrm{Cr}$ (VI)-contaminated soil and has the ability to reduce $\mathrm{Cr}$ (VI), found in biofilm was associated with glucose fermentation [37]. Geobacter species [38-40] and Shewanella species [41-43], known as transferring electrons directly to anode surface, were not found in our study. It's presumably due to that their presence was below the detection limit or they grow in suspension.

\subsection{Perspective}

Our results successfully demonstrate electricity production is possible from lab-scale MFC fed with macroalgae hydrolysate. Though promising, more efforts are still required. For example, substantial optimization will be required for further commercialization. Some parameters such as external resistance, anode material, initial TCOD loading need to be further investigated for providing a deep insight of the practical application.

Generating other products other than electricity probably is feasible. For example, hydrogen production in microbial electrolysis cell powered by the same macroalgae hydrolysate could be an alternative approach for using macroalgal biomass. 


\section{Conclusions}

This study demonstrated effective electricity generation and utilization of $L$. digitata biomass in MFC. After hydrolysis, high concentrations of glucose $\left(42.67 \mathrm{~g} \mathrm{~L}^{-1}\right)$ and mannitol $\left(15.70 \mathrm{~g} \mathrm{~L}^{-1}\right)$ were formed. TCOD removal efficiency achieved was over $95 \%$ with coulombic efficiency of approx. $11 \%$. The main degradation pathway was from six to four hydrocarbon compound (mainly isobutyrate) and then to $\mathrm{CO}_{2}$. Anodic $\mathrm{pH}$ tended to become acidic, while cathodic $\mathrm{pH}$ increased was over 8 . The 16S rRNA gene analysis showed a diverse microbial community which were consistent with VFA results. The results provide an insight of macroalgae utilization for sustainable energy production.

\section{Acknowledgements}

The authors would also like to acknowledge the technical assistance by Hector Gracia with analytical measurements. The authors would like to acknowledge China Scholarship Council for the financial support. This research was supported financially by The Danish Council for Independent Research (DFF-1335-00142) and Novo Nordisk Foundation (NNF16OC0021568). 


\section{References}

[1] H.M. Breunig, L. Jin, A. Robinson, C.D. Scown, Bioenergy Potential from Food Waste in California, Environmental Science \& Technology, 51 (2017) 1120-1128.

[2] A. Giwa, A. Alabi, A. Yusuf, T. Olukan, A comprehensive review on biomass and solar energy for sustainable energy generation in Nigeria, Renewable \& Sustainable Energy Reviews, 69 (2017) 620-641.

[3] C.G. Ozoegwu, C. Eze, C.O. Onwosi, C.A. Mgbemene, P.A. Ozor, Biomass and bioenergy potential of cassava waste in Nigeria: Estimations based partly on rural-level garri processing case studies, Renewable \& Sustainable Energy Reviews, 72 (2017) 625-638.

[4] S. de Jong, R. Hoefnagels, E. Wetterlund, K. Pettersson, A. Faaij, M. Junginger, Cost optimization of biofuel production - The impact of scale, integration, transport and supply chain configurations, Applied Energy, 195 (2017) 1055-1070.

[5] M.T. Dominguez, M.M. Montiel-Rozas, P. Madejon, M.J. Diaz, E. Madejon, The potential of native species as bioenergy crops on trace-element contaminated Mediterranean lands, Science of the Total Environment, 590 (2017) 29-39.

[6] K. Bahartan, L. Amir, A. Israel, R.G. Lichtenstein, L. Alfonta, In Situ fuel processing in a microbial fuel cell, ChemSusChem, 5 (2012) 1820-1825.

[7] S.B. Velasquez-Orta, T.P. Curtis, B.E. Logan, Energy from algae using microbial fuel cells, Biotechnol Bioeng, 103 (2009) 1068-1076.

[8] M. Alvarado-Morales, I.B. Gunnarsson, I.A. Fotidis, E. Vasilakou, G. Lyberatos, I. Angelidaki, Laminaria digitata as a potential carbon source for succinic acid and bioenergy production in a biorefinery perspective, Algal Research, 9 (2015) 126-132.

[9] K. Kumar, S. Ghosh, I. Angelidaki, S.L. Holdt, D.B. Karakashev, M.A. Morales, D. Das, Recent developments on biofuels production from microalgae and macroalgae, Renewable and Sustainable Energy Reviews, 65 (2016) 235-249. 
[10] P. Schiener, K.D. Black, M.S. Stanley, D.H. Green, The seasonal variation in the chemical composition of the kelp species Laminaria digitata, Laminaria hyperborea, Saccharina latissima and Alaria esculenta, Journal of Applied Phycology, 27 (2014) 363-373.

[11] D.R. Lovley, Microbial fuel cells: novel microbial physiologies and engineering approaches, Current Opinion in Biotechnology, 17 (2006) 327-332.

[12] Y. Zhang, B. Min, L. Huang, I. Angelidaki, Electricity generation and microbial community response to substrate changes in microbial fuel cell, Bioresour Technol, 102 (2011) 1166-1173.

[13] S.K. Chaudhuri, D.R. Lovley, Electricity generation by direct oxidation of glucose in mediatorless microbial fuel cells, Nat Biotechnol, 21 (2003) 1229-1232.

[14] H.S. Lee, P. Parameswaran, A. Kato-Marcus, C.I. Torres, B.E. Rittmann, Evaluation of energyconversion efficiencies in microbial fuel cells (MFCs) utilizing fermentable and non-fermentable substrates, Water Res, 42 (2008) 1501-1510.

[15] Zhao, N.; Li, X.; Jin, X.; Angelidaki, I.; Zhang, Y., Integrated electrochemical-biological process as an alternative mean for ammonia monitoring during anaerobic digestion of organic wastes, Chemosphere 195 (2018) 735-741.

[16] Y. Zhang, L.G. Olias, P. Kongjan, I. Angelidaki, Submersible microbial fuel cell for electricity production from sewage sludge, Water Science \& Technology, 64 (2011) 50.

[17] Y. Zhang, Y. Wang, I. Angelidaki, Alternate switching between microbial fuel cell and microbial electrolysis cell operation as a new method to control $\mathrm{H} 2 \mathrm{O} 2$ level in Bioelectro-Fenton system, Journal of Power Sources, 291 (2015) 108-116.

[18] N. Zhao, I. Angelidaki, Y. Zhang, Electricity generation and microbial community in response to shortterm changes in stack connection of self-stacked submersible microbial fuel cell powered by glycerol, Water Res, 109 (2017) 367-374.

[19] P.G. Kougias, L. Treu, D.P. Benavente, K. Boe, S. Campanaro, I. Angelidaki, Ex-situ biogas upgrading and enhancement in different reactor systems, Bioresour Technol, 225 (2017) 429-437.

[20] A.I. Saeed, V. Sharov, J. White, J. Li, W. Liang, N. Bhagabati, J. Braisted, M. Klapa, T. Currier, M. Thiagarajan, A. Sturn, M. Snuffin, A. Rezantsev, D. Popov, A. Ryltsov, E. Kostukovich, I. Borisovsky, Z. 
Liu, A. Vinsavich, V. Trush, J. Quackenbush, TM4: A free, open-source system for microarray data management and analysis, Biotechniques, 34 (2003) 374-+.

[21] K.J. Chae, M.J. Choi, J.W. Lee, K.Y. Kim, I.S. Kim, Effect of different substrates on the performance, bacterial diversity, and bacterial viability in microbial fuel cells, Bioresour Technol, 100 (2009) 3518-3525.

[22] D. Pant, G. Van Bogaert, L. Diels, K. Vanbroekhoven, A review of the substrates used in microbial fuel cells (MFCs) for sustainable energy production, Bioresour Technol, 101 (2010) 1533-1543.

[23] Y. Zhang, B. Min, L. Huang, I. Angelidaki, Generation of electricity and analysis of microbial communities in wheat straw biomass-powered microbial fuel cells, Appl Environ Microbiol, 75 (2009) 33893395.

[24] A.E. Franks, K.P. Nevin, H.F. Jia, M. Izallalen, T.L. Woodard, D.R. Lovley, Novel strategy for threedimensional real-time imaging of microbial fuel cell communities: monitoring the inhibitory effects of proton accumulation within the anode biofilm, Energy \& Environmental Science, 2 (2009) 113-119.

[25] Y. Yang, Y. Xiang, G. Sun, W.M. Wu, M. Xu, Electron acceptor-dependent respiratory and physiological stratifications in biofilms, Environ Sci Technol, 49 (2015) 196-202.

[26] X.C. Quan, Y.P. Quan, K. Tao, X.M. Jiang, Comparative investigation on microbial community and electricity generation in aerobic and anaerobic enriched MFCs, Bioresource Technology, 128 (2013) 259265.

[27] S.B. Velasquez-Orta, E. Yu, K.P. Katuri, I.M. Head, T.P. Curtis, K. Scott, Evaluation of hydrolysis and fermentation rates in microbial fuel cells, Applied Microbiology and Biotechnology, 90 (2011) 789-798.

[28] L. Lu, T. Huggins, S. Jin, Y. Zuo, Z.J. Ren, Microbial metabolism and community structure in response to bioelectrochemically enhanced remediation of petroleum hydrocarbon-contaminated soil, Environ Sci Technol, 48 (2014) 4021-4029.

[29] C. Militon, D. Boucher, C. Vachelard, G. Perchet, V. Barra, J. Troquet, E. Peyretaillade, P. Peyret, Bacterial community changes during bioremediation of aliphatic hydrocarbon-contaminated soil, Fems Microbiology Ecology, 74 (2010) 669-681.

[30] S. Jung, J.M. Regan, Comparison of anode bacterial communities and performance in microbial fuel cells with different electron donors, Appl Microbiol Biotechnol, 77 (2007) 393-402. 
[31] Y.F. Choo, J. Lee, I.S. Chang, B.H. Kim, Bacterial communities in microbial fuel cells enriched with high concentrations of glucose and glutamate, Journal of Microbiology and Biotechnology, 16 (2006) 14811484.

[32] K. Rabaey, N. Boon, S.D. Siciliano, M. Verhaege, W. Verstraete, Biofuel cells select for microbial consortia that self-mediate electron transfer, Applied and Environmental Microbiology, 70 (2004) 5373-5382. [33] R.A. Timmers, M. Rothballer, D. Strik, M. Engel, S. Schulz, M. Schloter, A. Hartmann, B. Hamelers, C. Buisman, Microbial community structure elucidates performance of Glyceria maxima plant microbial fuel cell, Applied Microbiology and Biotechnology, 94 (2012) 537-548.

[34] T. Hori, A. Muller, Y. Igarashi, R. Conrad, M.W. Friedrich, Identification of iron-reducing microorganisms in anoxic rice paddy soil by C-13-acetate probing, Isme Journal, 4 (2010) 267-278.

[35] A.P. Borole, C.Y. Hamilton, T. Vishnivetskaya, D. Leak, C. Andras, Improving power production in acetate-fed microbial fuel cells via enrichment of exoelectrogenic organisms in flow-through systems, Biochemical Engineering Journal, 48 (2009) 71-80.

[36] Y. Jangir, S. French, L.M. Momper, D.P. Moser, J.P. Amend, M.Y. El-Naggar, Isolation and Characterization of Electrochemically Active Subsurface Delftia and Azonexus Species, Front Microbiol, 7 (2016) 756.

[37] K.S. Inglett, H.S. Bae, H.C. Aldrich, K. Hatfield, A.V. Ogram, Clostridium chromiireducens sp nov., isolated from Cr(VI)-contaminated soil, Int. J. Syst. Evol. Microbiol., 61 (2011) 2626-2631.

[38] J.T. Babauta, H. Beyenal, Mass Transfer Studies of Geobacter sulfurreducens Biofilms on Rotating Disk Electrodes, Biotechnology and Bioengineering, 111 (2014) 285-294.

[39] A.E. Franks, K.P. Nevin, R.H. Glaven, D.R. Lovley, Microtoming coupled to microarray analysis to evaluate the spatial metabolic status of Geobacter sulfurreducens biofilms, Isme Journal, 4 (2010) 509-519.

[40] D.R. Bond, D.R. Lovley, Electricity production by Geobacter sulfurreducens attached to electrodes, Applied and Environmental Microbiology, 69 (2003) 1548-1555.

[41] B.E. Logan, Exoelectrogenic bacteria that power microbial fuel cells, Nat. Rev. Microbiol., 7 (2009) $375-381$. 
[42] D. Choi, S.B. Lee, S. Kim, B. Min, I.G. Choi, I.S. Chang, Metabolically engineered glucose-utilizing Shewanella strains under anaerobic conditions, Bioresource Technology, 154 (2014) 59-66.

[43] B.R. Ringeisen, E. Henderson, P.K. Wu, J. Pietron, R. Ray, B. Little, J.C. Biffinger, J.M. Jones-Meehan, High power density from a miniature microbial fuel cell using Shewanella oneidensis DSP10, Environmental Science \& Technology, 40 (2006) 2629-2634. 


\section{Community structure}
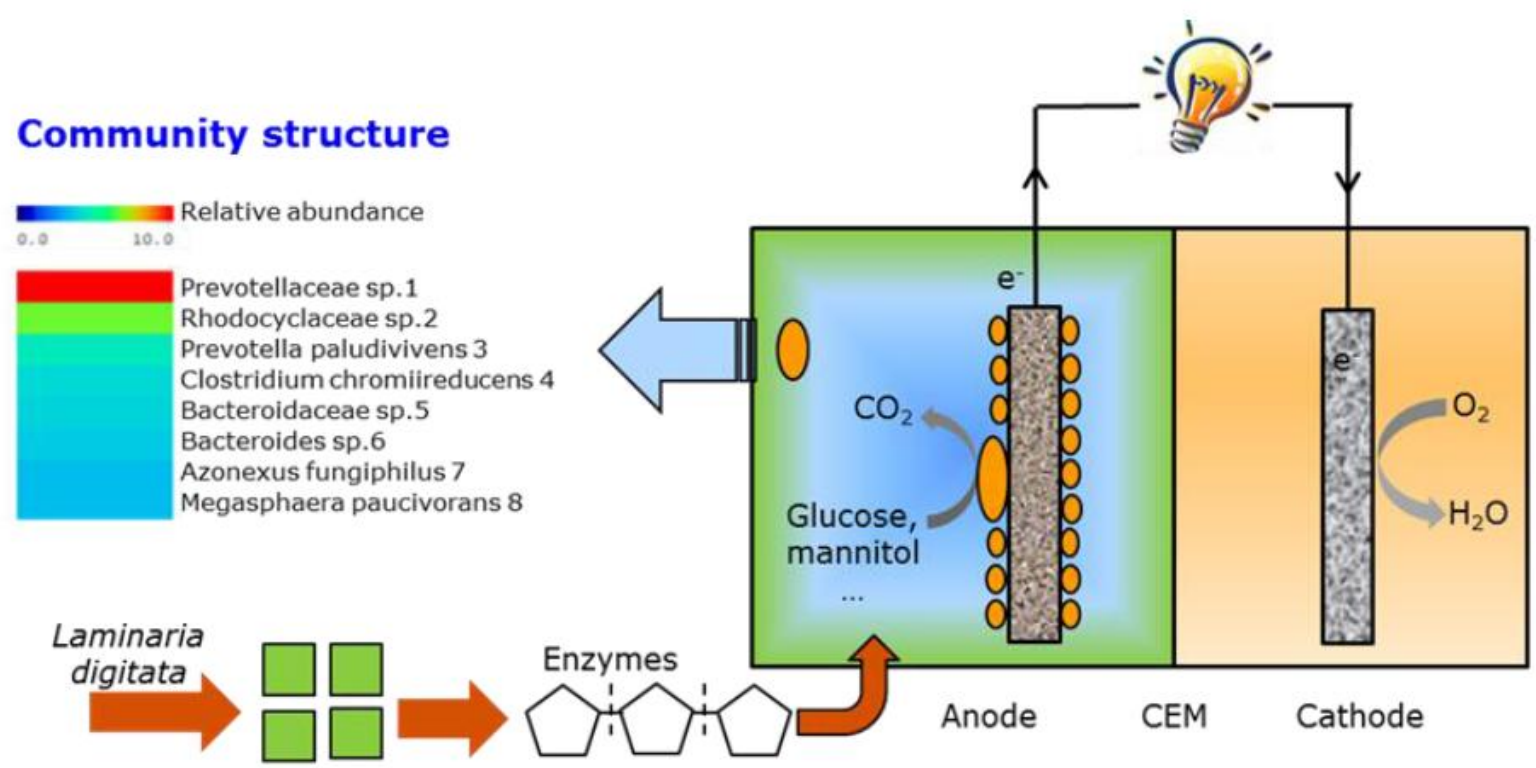

Pretreatment

Hydrolysis

Microbial fuel cell

Graphical abstract 


\section{Highlights}

- The utilization of macroalgae Laminaria digitata in microbial fuel cell.

- High contents of glucose and mannitol enriched in hydrolysate of $L$. digitata.

- Good performance of MFC in terms of COD removal and power density.

- Glucose and mannitol degraded through isobutryrate as intermediate.

- Microbial communities consistent with volatile fatty acid results. 